THE INFLUENCE OF GOOD CORPORATE GOVERNANCE (GCG) MECHANISMS AND

TRANSPARENCY ON FINANCIAL PERFORMANCE IN COMPANIES LISTED IN

INDONESIA STOCK EXCHANGE 2019

\title{
PENGARUH MEKANISME GOOD CORPORATE GOVERNANCE (GCG) DAN TRANSPARANSI TERHADAP KINERJA KEUANGAN PADA PERUSAHAAN YANG TERDAFTAR DI BURSA EFEK INDONESIA TAHUN 2019
}

\author{
Oleh: \\ Suridar Sanah ${ }^{1)}$ Mukhzarudfa ${ }^{2)}$ Tona Aurora L $\mathbf{L}^{3)}$ \\ ${ }^{1)}$ Alumni Magister Ilmu Akuntansi Pascasarjana Universitas Jambi Tahun 2021 \\ ${ }^{2 \& 3)}$ Fakultas Ekonomi dan Bisnis Universitas Jambi - Indonesia \\ Email : suridars@gmail.com ${ }^{1)}$,mukhzarudfa@unja.ac.id ${ }^{2)}$,tonalubis@gmail.com ${ }^{3)}$
}

\begin{abstract}
ABSTRACK
This study aims to examine the effect of good corporate governance (GCG) mechanisms on financial performance through transparency. The independent variables in this study are management structure and ownership structur. The moderating variable in this study is transparency. The dependent variable is financial performance. The sample in this study were companies listed on the Indonesia stock exchange in 2019 obtained by the purposive sampling method. The number of samples in this study were 47 companies. The result of this study indicate that (1) management structure effects financial performance, (2) management structure effects transparency, (3) ownership structure does not effect financial performance, (4) ownership structure does not effect transparency, (5) transparency does not effect on financial performance, (6) management structure has no effect on financial performance through transparency, and (7) ownership structure has no effect on financial performance through transparency.
\end{abstract}

Keywords: Mechanisms of good corporate governance, transparency, and financial performance.

\begin{abstract}
ABSTRAK
Penelitian ini bertujuan untuk menguji pengaruh mekanisme good corporate governance (GCG) terhadap kinerja keuangan melalui transparansi. Variabel independen dalam penelitian ini adalah struktur pengelolaan dan struktur kepemilikan. Variabel moderasi dalam penelitian ini adalah transparansi. Variabel dependen adalah kinerja keuangan.Sampel dalam penelitian ini adalah perusahaan yang terdaftar di Bursa Efek Indonesia tahun 2019 diperoleh dengan metode purposive sampling. Jumlah sampel dalam penelitian ini adalah sebanyak 47 perusahaan. Hasil penelitian ini menunjukkan bahwa (1) stuktur pengelolaan berpengaruh terhadap kinerja keuangan, (2) struktur pengelolaan berpengaruh terhadap transparansi, (3) struktur kepemilikan tidak berpengaruh terhadap kinerja keuangan, (4) struktur kepemilikan tidak berpengaruh terhadap transparansi, (5) transparansi tidak berpengaruh terhadap kinerja keuangan, (6) struktur pengelolaan tidak berpengaruh terhadap kinerja keuangan melalui transparansi, dan (7) struktur kepemilikan tidak berpengaruh terhadap kinerja keuangan melalui transparansi.
\end{abstract}

Kata Kunci: Mekanisme Good Corporate Governance, Transparansi, dan Kinerja Keuangan 


\section{PENDAHULUAN}

\subsection{Latar Belakang}

Peningkatan ekonomi yang baik dapat terwujud salah satunya dengan mengedepankan good corporate governance (GCG) yang merupakan suatu konsep tata kelola perusahaan yang baik serta menyiapkan kerangka kerja tata kelola yang meliputi misi yang akan dicapai, aturan-aturan, dan konveksi yang jelas untuk pedoman pencapaian misi (Erniwati, 2020). Good Corporate Governance (GCG) merupakan sistem yang mampu memberikan perlindungan dan jaminan hak kepada stakeholder, termasuk di dalamnya adalah shareholders, lenders, employess, executives, government, customers, dan stakeholders yang lain (Hastuti, 2005).

Penerapan Good Corporate Governance (GCG) pada saat ini bukan lagi sekedar kewajiban, namun telah menjadi kebutuhan bagi setiap perusahaan dan organisasi (Arifani, 2012). Good Corporate Governance (GCG) diperlukan untuk memberikan perkembangan yang baik terhadap kinerja suatu perusahaan yang menjadikan perusahaan berumur panjang dan bisa dipercaya.

Pengungkapan tepat waktu dan informasi yang akurat merupakan bagian yang terpenting dari good corporate governance. Penerapan corporate governance dapat meningkatkan transparansi perusahaan. Transparansi telah diakui secara luas oleh akademisi dan regulator pasar, sehingga banyak aturan dan peraturan yang diperkenalkan dari waktu ke waktu untuk memastikan perusahaan melakukan transparansi (Ramadhani et al., 2020).

Informasi yang diungkapkan dalam laporan tahunan emiten dapat dikelompokkan menjadi dua yaitu pengungkapan wajib (mandatory disclousure) dan pengungkapan sukarela (voluntary disclousure). Pengungkapan wajib adalah informasi yang harus diungkapkan oleh emiten yang diatur oleh peraturan pasar modal suatu negara (Nuswandari, 2009). Sedangkan, pengungkapan sukarela merupakan penyampaian informasi yang diberikan secara sukarela oleh perusahaan diluar pengungkapan wajib.

Penelitian ini meneliti mekanisme good corporate governance yang dilihaat dari sisi struktur pengelolaan dan stuktur kepemilikan. Good corporate governance (GCG) yang dilihat dari sisi struktur pengelolaan seperti dewan komisaris, dewan direksi, dan komite audit. Arifani (2012) menjelaskan dewan komisaris merupakan puncak dari sistem pengelolaan internal perusahaan yang memiliki peranan terhadap aktivitas pengawasan. Sedangkan untuk dewan direksi berfungsi untuk mengurus perusahaan (Effendi, 2016). Komite audit bertanggung jawab untuk mengawasi laporan keuangan, mengawasi audit eksternal, dan mengamati sistem pengendalian internal (termasuk audit internal) (Arifani, 2012).

Good corporate governance (GCG) yang dilihat dari sisi struktur kepemilikan seperti kepemilikan keluarga, kepemilikan institusi, dan kepemilikan manajerial. Kepemilikan keluarga adalah perusahaan yang berdiri, dimiliki, diawasi, serta dijalankan oleh sekelompok orang yang memiliki ikatan darah atau pernikahan serta memiliki mayoritas saham suatu perusahaan (Utami, 2019). Kepemilikan institusi adalah proporsi kepemilikan saham oleh institusi seperti LSM, perusahaan swasta, perusahaan efek, dana pensiun, perusahaan asuransi, bank dan perusahaan - perusahaan investasi (Wiranata \& Nugrahanti, 2013). Kemudian, Jensen \& Meckling (1976) menjelaskan kepemilikan saham oleh manajer dapt mensejajarkan kepentingan manajer dan pemegang saham karena dengan memiliki saham perusahaan, manajer akan merasakan langsung manfaat dari setiap keputusan yang diambilnya.

Salah satu konsep menjaga kestabilan good corporate governance (GCG) yaitu dengan meningkatkan kinerja keuangan (Erniwati, 2020). Tujuan utama didirikannya perusahaan ialah untuk meningkatkan kesejahteraan pemegang saham. Kesejahteraan pemegang saham dapat ditingkatkan melalui kinerja perusahaan, perusahaan yang memiliki kinerja yang baik memiliki makna bagi konsumen, komunitas, karyawan, dan pemasok termasuk dalam pemasok adalah kreditur yaitu pemasok dana (Astuti, 2015).

Kinerja keuangan diukur menggunakan return on asset/ROA dan retun on equity/ROE. Return on Asset (ROA) dapat menunjukkan efektivitas kinerja perusahaan dalam penggunaan aset untuk menghasilkan keuntungan pada suatu periode. Semakin tinggi ROA, semakin baik maksudnya perusahaan berhasil mengelola asetnya dengan baik dan informasi tersebut diungkapkan dalam laporan keuangan dan laporan tahunan yang digunakan oleh investor sebagai pertimbangan sebelum menanamkan dananya di perusahaan (Lastanti \& Salim, 2019). ROA dapat mengukur kemampuan perusahaan dalam menghasilkan keuntungan operasi dengan total aktiva yang ada (Candradewi \& Sedana, 2016).

Return on Equity (ROE) merupakan kemampuan manajemen perusahaan dalam mengelola modal yang tersedia untuk mendapatkan net income yang tersedia bagi pemegang saham (Erniwati, 2020). Hal ini menunjukkan semakin besar ROE perusahaan, maka semakin besar pula tingkat keuntungan yang dicapai perusahaan untuk memanfaatkan modal yang dimiliki perusahaan (Erniwati, 2020).

\subsection{Rumusan Masalah}

Berdasarkan latar belakang masalah yang telah diuraikan, maka pokok permasalahan penelitian ini dapat dirumuskan bagaimanakah pengaruh dari struktur pengelolaan dan struktur kepemilikan terhadap kinerja keuangan melalui transparansi pada perusahaan yang terdaftar di Bursa Efek Indonesia Tahun 2019?.

\subsection{Tujuan Penelitian}

Untuk menganalisis dan memperoleh bukti Berdasarkan latar belakang dan rumusan masalah yang telah di paparkan sebelumnya, adapun tujuan dari 
penelitian ini adalah untuk membuktikan secara empiris dan menganalisis dari pengaruh struktur pengelolaan dan struktur kepemilikan terhadap kinerja keuangan melalui transparansi pada perusahaan yang terdaftar di Bursa Efek Indonesia tahun 2019.

\section{KAJIAN PUSTAKA DAN PERUMUSAN HIPOTESIS}

\subsection{Agency Theory}

Jensen \& Meckling (1976) menyatakan teori keagenan atau agency theory merupakan gambaran hubungan antara pihak yang memiliki wewenang yakni investor yang juga biasa disebut dengan principal dengan para manajer yang merupakan agen yang diberi wewenang. Hubungan antara agen dan prinsipal ini disebut dengan hubungan keagenan (Wijaya \& Christiawan, 2014).

Pemilik atau principal akan mendelegasikan otoritas pembuatan keputusan kepada manajer, hal ini dilakukan agar hubungan kontraktual tersebut dapat berjalan dengan baik. Perencanaan kontrak yang tepat berguna untuk menyelaraskan kepentingan manajer dan pemilik mengenai konflik dan kepentingan, karena hal ini merupakan inti dalam teori keagenan (Wijaya \& Christiawan, 2014).

Para manajer atau agen yang telah memiliki kontrak dengan para investor harus dapat mempertanggung-jawabkan kewajibannya sebagai pihak internal yang mengetahui semua seluk beluk perusahaan demi tercapainya tujuan perusahaan. Maka, hal ini dapat menimbulkan ketidakseimbangan informasi (asymmetry information) antara pihak internal dan pihak eksternal, dengan begitu pihak internal dapat menyembunyikan informasi-informasi yang tidak diketahui oleh pihak eksternal (Wijaya \& Christiawan, 2014).

Asimetri informasi merupakan suatu keadaan dimana manajer memiliki akses informasi atas prospek perusahaan yang tidak dimiliki oleh pihak luar perusahaan (Agusti \& Pramesti, 2013). Konflik keagenan dapat terjadi ketika agen tidak berbuat sesuai dengan kepentingan prinsipal (Jensen \& Meckling, 1976), jika hal ini terjadi dapat memicu biaya keagenan (agency cost). Hunardy \& Tarigan (2017) menjelaskan sesuai dengan teori keagenan bahwa kinerja perusahaan dapat menurun akibat masalah yang terjadi antara manajer dan pemegang saham (conflict of interest). Namun, hubungan antara manajer dan pemegang saham dapat dikendalikan, maka kinerja perusahaan akan menjadi lebih baik. Konflik kepentingan antara agent dan principal dapat dikurangi dengan mekanisme pengawasan yang dapat menyelaraskan berbagai kepentingan yang ada di perusahaan dengan menerapkan good corporate governance. Metode good corporate governance yang digunakan adalah struktur kepemilikan dan struktur pengelolaan. Struktur kepemilikan merupakan salah satu mekanisme dari good corporate governance yang didesain untuk meminimalkan agency conflict antara manager dengan pemegang saham (Hunardy \& Tarigan, 2017).

\subsection{Good Corporate Governance}

Claessens (2006) mendefinisikan tata kelola perusahaan kedalam dua kategori, yaitu: (1) Rangkaian kategori pertama berkaitan dengan sekumpulan pola perilaku, kinerja, efisiensi dan stuktur keuangan; (2) Perangkat kedua berkaitan dengan kerangka normatif yaitu aturan dimana perusahaan beroperasi, dengan aturan yang berasal dari sumber seperti sumber hukum, sistem peradilan, pasar keuangan, dan pasar faktor.

Organization for Economic Cooperation and Development (OECD) pada April 1998 telah mengeluarkan seperangkat prinsip good corporate governance yang dikembangkan secara universal, adapun prinsip-prinsip tersebut adalah sebagai berikut (Dahlan, 2019):

- Fairness (Kewajaran dan Kesetaraan), menjamin perlindungan hak-hak pemegang saham termasuk hak-hak pemegang saham minoritas dan para pemegang saham asing serta menjamin terlaksananya komitmen para investor.

- Transparancy (transparansi), mewajibkan adanya suatu informasi yang terbuka, tepat waktu, serta jelas dan dapat diperbandingkan yang menyangkut keadaan keuangan, pengelolaan perusahaan dan kepemilikan perusahaan.

- Accountability (akuntabilitas), menjelaskan peran dan tanggung jawab serta mendukung usaha untuk menjamin penyeimbangan kepentingan manajemen dan pemegang saham, sebagaimana yang diwarisi oleh dewan komisaris.

- Responsibility (pertanggungjawaban), memastikan dipatuhinya peraturan serta ketentuan yang berlaku sebagai cermin dipatuhinya nilai-nilai sosial.

\subsection{Struktur Pengelolaan}

Indikator dari struktur pengelolaan dalam penelitian ini adalah dewan komisaris, dewan direksi, dan komite audit. Dewan Komisaris merupakan inti dari corporate governance yang ditugaskan untuk menjamin pelaksanaan strategi perusahaan, mengawasi manajemen dalam mengelola perusahaan, serta mewajibkan terlaksananya akuntabilitas (Rahmawati, 2017). Dewan komisaris merupakan salah satu fungsi kontrol yang terdapat dalam suatu perusahaan. Fungsi kontrol yang dilakukan oleh dewan komisaris merupakan salah satu bentuk praktis dari teori agensi (Sukandar, 2014). Sedangkan, untuk dewan direksi berdasarkan Pasal 1 dalam UU No. 40 tahun 2007 tentang perseroan terbatas, yang dimaksud dengan direksi adalah organ perseroan yang berwenang dan bertanggung jawab penuh atas pengurusan perseroan untuk kepentingan perseroan, sesuai dengan maksud dan tujuan perseroan, serta mewakili perseroan, baik didalam maupun diluar pengadilan, sesuai dengan ketentuan anggaran dasar (Effendi, 2016). Kemudian 
untuk komite audit berdasarkan Ikatan Komite Audit Indonesia mendefinisikan komite audit sebagai suatu komite yang bekerja secara profesional dan independen yang dibentuk oleh dewan komisaris, dengan demikian tugasnya adalah membantu dan memperkuat fungsi dewan komisaris dalam menjalankan fungsi pengawasan atas proses pelaporan keuangan, manajemen risiko, pelaksanaan audit, dan implementasi dari corporate governance di perusahaan - perusahaan (Fransisca W, 2013).

\subsection{Struktur Kepemilikan}

Kepemilikan saham pada penelitian ini yaitu kepemilikan saham keluarga, kepemilikan institusional, dan kepemilikan manajerial. Kepemilikan saham keluaga adalah perusahaan yang berdiri, dimiliki, diawasi, serta dijalankan oleh sekelompok orang yang memiliki ikatan darah atau pernikahan serta memiliki mayoritas saham suatu perusahaan (Utami, 2019). Kekayaan anggota keluarga sangat bergantung pada nilai perusahaan, hal ini menyebabkan keluarga mempunyai insentif yang besar untuk mengawasi karyawan serta menciptakan loyalitas jangka panjang karyawan (Dewi et al., 2018). Wiranata \& Nugrahanti (2013) menyatakan keberadaan investor institusional dianggap bisa mengoptimalkan pengawasan kinerja manajemen dengan memonitoring setiap keputusan yang diambil oleh pihak manajemen selaku pengelola perusahaan. Kepemilikan institusional didefinisikan sebagai presentase saham yang dimiliki oleh semua investor institusional di perusahaan (Tsai \& Tung, 2014;Shin-Ping \& Tsung-Hsien, 2009). Kepemilikan manajerial adalah para pemegang saham yang juga disebut sebagai pemilik perusahaan yang mempunyai tugas dan wewenang serta aktif ikut dalam pengambilan keputusan pada perusahaan (dewan komisaris dan dewan direksi) (Rivandi, 2018). Jensen \& Meckling (1976) menjelaskan kepemilikan saham oleh manajer dapt mensejajarkan kepentingan manajer dan pemegang saham karena dengan memiliki saham perusahaan, manajer akan merasakan langsung manfaat dari setiap keputusan yang diambilnya.

\subsection{Transparansi}

Transparansi merupakan keterbukaan dalam melaksanakan proses pengambilan keputusan dan keterbukaan dalam mengemukakan informasi materil dan relevan mengenai perusahaan (Effendi, 2016). Pengungkapan laporan tahunan perusahaan dapat dikelompokkan menjadi dua, yaitu pengungkapan yang bersifat wajib dan pengungkapan yang bersifat sukarela. Pengungkapan wajib adalah pengungkapan minimum yang disyaratkan oleh standar akuntansi yang berlaku (Amrin, 2018). Pengungkapan sukarela adalah pengungkapan yang dilakukan oleh manajemen perusahaan melebihi pengungkapan wajib yang diharuskan oleh standar akuntansi yang berlaku (Amrin, 2018).

\subsection{Kinerja Keuangan}

Kinerja keuangan adalah kemampuan perusahaan untuk menghasilkan keuntungan pada tingkat penjualan, aset, dan modal tertentu yang pertumbuhannya menjadi indikator penting bagi investor dalam menilai prospek perusahaan dimasa depan (Lastanti \& Salim, 2019). Return on Asset (ROA) dapat menunjukkan efektivitas kinerja perusahaan dalam penggunaan aset untuk menghasilkan keuntungan pada suatu periode. Semakin tinggi ROA, semakin baik maksudnya perusahaan berhasil mengelola asetnya dengan baik dan informasi tersebut diungkapkan dalam laporan keuangan dan laporan tahuan yang digunakan oleh investor sebagai pertimbangan sebelum menanamkan dananya di perusahaan (Lastanti \& Salim, 2019). Return on Equity (ROE) adalah rasio yang digunakan untuk mengukur keuntungan bersih yang diperoleh dari pengelolaan modal yang diinvestasikan oleh pemilik perusahaan. Angka ROE yang semakin tinggi memberikan indikasi bagi pemegang saham bahwa tingkat pengembalian investasi yang semakin tinggi.

\subsection{Model Penelitian}

Adapun model dalam penelitian ini adalah sebagai berikut:

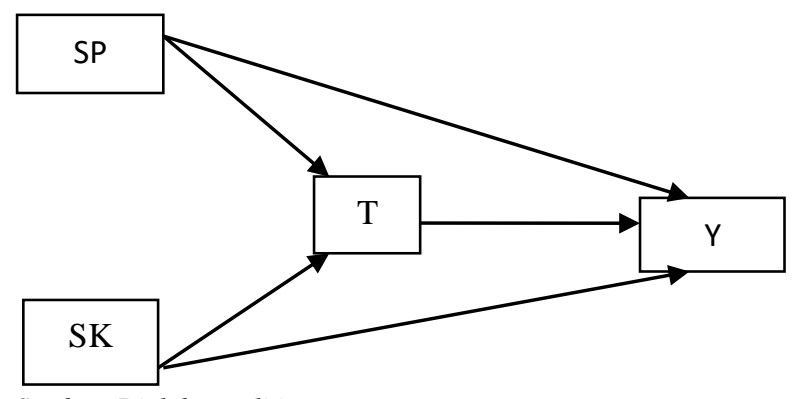

Sumber: Diolah peneliti

Gambar 1. Model Penelitian

Keterangan:

$\longrightarrow \quad$ : Hubungan antar variabel secaraparsial

SP : Struktur Pengelolaan

SK : Struktur Kepemilikan

T : : Transparansi

Y : Kinerja keuangan

\subsection{Hipotesis}

$\mathrm{H}_{1} \quad$ Struktur pengelolaan berpengaruh terhadap kinerja keuangan.

$\mathrm{H}_{2}$ Struktur pengelolaan berpengaruh terhadap transparansi.

$\mathrm{H}_{3}$ Struktur kepemilikan berpengaruh terhadap kinerja keuangan.

$\mathrm{H}_{4}$ Struktur kepemilikan berpengaruh terhadap transparansi.

$\mathrm{H}_{5}$ Transparansi berpengaruh terhadap kinerja keuangan.

$\mathrm{H}_{6} \quad$ Struktur pengelolaan berpengaruh terhadap kinerja keuangan melalui transparansi. 
$\mathrm{H}_{7} \quad$ Struktur Kepemilikan berpengaruh terhadap kinerja keuangan melalui transparansi.

\section{METODE PENELITIAN}

\subsection{Populasi dan Sampel}

Populasi dalam penelitian ini adalah seluruh perusahaan yang terdaftar di Bursa Efek Indonesia (BEI) periode tahun 2019. Populasi perusahaan yang terdaftar di BEI pada tahun 2019 adalah sebanyak 716 perusahaan.

Kriteria yang digunakan dalam penelitian ini berdasarkan penggunaan metode purposive sampling, dengan kriteria sebagai berikut:

1. Perusahaan yang terdaftar di bursa efek Indonesia tahun 2019.

2. Perusahaan melaporkan laporan keuangan tahunan (annual report) tahun 2019.

3. Perusahaan yang menyajikan data secara lengkap yang sesuai dengan variabel yang akan diteliti tahun 2019.

\subsection{Operasional Variabel}

Variabel dalam penelitian ini terdiri dari variabel independen adalah struktur pengelolaan dan struktur kepemilikan, variabel moderasi yaitu transparansi, dan variabel dependen dalam penelitian adalah kinerja keuangan.

3.2.1 Struktur Pengelolaan $\left(\mathrm{X}_{1}\right)$

1. Dewan komisaris

$=\sum$ anggota dewan komisaris

2. Dewan Direksi

$=\sum$ ang gota dewan direksi

3. Komite audit

$=\sum$ anggota komite audit

3.2.2 Struktur Kepemilikan $\left(\mathrm{X}_{2}\right)$

1. Kepemilikan keluarga

Jumlah Saham pihak Keluarga

$=\overline{\text { Total saham yang beredar }}$

2. Kepemilikan Institusional

Jumlah saham pihak institusional

$=\quad \times 100 \%$

total saham yang beredar

3. Kepemilikan manajerial

Jumlah saham pihak manajerial

$=$

total saham yang beredar
3.2.3 Transparansi

1. Pengungkapan sukarela

$$
=\frac{\text { item yang di ungkapan }}{\text { Jumlah seluruh item yang diungkapkan }}
$$$$
=
$$

2. Pengungkapan wajib

$$
=\frac{\text { Item yang diungkapkan }}{\text { Jumlah seluruh item yang diungkapkan }}
$$

3.2.4 Kinerja keuangan

1. Return On Asset (ROA)

$$
\mathrm{ROA}=\frac{\text { Net Income }}{\text { Total Aset }} \times 100 \%
$$

2. Return On Equity (ROE)

$$
\mathrm{ROE}=\frac{\text { Laba Bersih }}{\text { Total Equity }} \times 100 \%
$$

\subsection{Metode Analasis Data}

Dalam penelitian ini analisis data dilakukan dengan menggunakan PLS. PLS merupakan alternatif olah data dari pendekatan SEM yang berbasis coverlance menjadi berbasis variant (Syukriyah, 2020). Pengujian model struktural dalam PLS dilakukan dengan bantuan software SmartPLS versi 3.0 for windows. Structural equation modelling (SEM) merupakan suatu metode yang digunakan untuk menutup kelemahan yang terdapat pada metode regresi. Partial Least Square merupakan metode analisis yang powerfull yang mana dalam metode ini tidak didasarkan banyaknya asumsi.

\section{HASIL DAN PEMBAHASAN 4.1. Statistik Deskriptif}

Tabel 1. Hasil Statistik Deskriptif

\begin{tabular}{|l|l|l|l|l|l|}
\hline Variabel & Mean & Min & Max & $\begin{array}{l}\text { Standar } \\
\text { Deviasi }\end{array}$ & $\begin{array}{l}\text { N } \\
\text { Jumlah } \\
\text { Observasi })\end{array}$ \\
\hline DK & 3,745 & 2,00 & 8,00 & 1,391 & 47 \\
\hline DD & 4,532 & 2,00 & 9,00 & 1,541 & 47 \\
\hline KA & 2,957 & 2,00 & 4,00 & 0,289 & 47 \\
\hline PS & 61,936 & 1,00 & 99,00 & 45,828 & 47 \\
\hline PW & 13,234 & 1,00 & 99,00 & 31,990 & 47 \\
\hline KK & 40,319 & 0,00 & 93,00 & 30,987 & 47 \\
\hline KI & 37,362 & 2,00 & 97,00 & 27,031 & 47 \\
\hline KM & 4417,340 & 0,00 & 41963,00 & 9098,955 & 47 \\
\hline ROA & 7,234 & $-338,00$ & 201,00 & 85,329 & 47 \\
\hline ROE & $-16,872$ & $-1484,00$ & 416,00 & 279,143 & 47 \\
\hline
\end{tabular}

Sumber: Hasil pengolahan data dengan SPSS

1. Variabel Dewan komisaris memiliki nilai minimum sebesar 2,00, nilai maksimum sebesar 8,00, untuk nilai rata - rata sebesar 3,7447 , dan nilai sebesar 1,391 untuk standar deviasi.

2. Variabel dewan direksi mempunyai nilai minimum sebesar 2,00 dan nilai maksimum sebesar 9,00, untuk nilai rata - rata sebesar 4,532 dan nilai sebesar 1,541 untuk standar deviasi. 
3. Variabel komite audit mempunyai nilai minimum sebesar 2,00 dan nilai maksimum sebesar 4,00, untuk nilai rata - rata sebesar 2,957 dan nilai sebesar 0,289 untuk standar deviasi.

4. Variabel pengungkapan sukarela mempunyai nilai minimum sebesar 1,00 dan nilai maksimum sebesar 99,00, untuk nilai rata - rata sebesar 61,936 dan nilai sebesar 45,828 untuk standar deviasi.

5. Variablel pengungkapan wajib mempunyai nilai minimum sebesar 1,00 dan nilai maksimum sebesar 99,00, untuk nilai rata - rata sebesar 13,234 dan nilai sebesar 31,990 untuk standar deviasi.

6. Variabel kepemilikan keluarga mempunyai nilai minimum sebesar 0,00 dan nilai maksimum sebesar 93,00, untuk nilai rata - rata sebesar 40,319 dan nilai sebesar 30,987 untuk standar deviasi.

7. Variabel kepemilikan institusi mempunyai nilai minimum sebesar 2,00 dan nilai maksimum sebesar 97,00, untuk nilai rata - rata sebesar 37,362 dan nilai sebesar 27,031 untuk standar deviasi.

8. Variabel kepemilikan manajerial mempunyai nilai minimum sebesar 0,00 dan nilai maksimum sebesar 41963,00, untuk nilai rata - rata sebesar 4417,340 dan nilai sebesar 9098,995 untuk standar deviasi.

9. Variabel return on asset/ROA mempunyai nilai minimum sebesar $-338,00$ dan nilai maksimum sebesar 201,00, untuk nilai rata - rata sebesar 7,234 dan nilai sebesar 279,143 untuk standar deviasi.

10. Variabel return on equity/ROE mempunyai nilai minimum sebesar $-1484,00$ dan nilai maksimum sebesar 416,00, untuk nilai rata - rata sebesar 16,872 dan nilai sebesar 279,143 untuk standar deviasi.

\subsection{Pengujian Measurement (outer) model}

\subsubsection{Convergent validity}

Untuk menguji Convergent validity digunakan nilai outer loading atau loading factor. Suatu indikator dinyatakan memenuhi convergent validity dalam kategori baik apabila nilai outer loading > 0,7.

Tabel 2. Nilai Loading Faktor Pada Indikator Untuk Masing - Masing Variabel Laten

\begin{tabular}{|l|l|l|l|l|}
\hline & $\begin{array}{l}\text { Kinerja } \\
\text { Keuangan } \\
\text { Y }\end{array}$ & $\begin{array}{l}\text { Struktur } \\
\text { Pengelolaan } \\
\text { X1 }\end{array}$ & $\begin{array}{l}\text { Struktur } \\
\text { Kepemilikan } \\
\text { X2 }\end{array}$ & $\begin{array}{l}\text { Transpar } \\
\text { ansi Z }\end{array}$ \\
\hline DD & & 0,802 & & \\
\hline DK & & 0,844 & & \\
\hline KA & & 0,537 & & \\
\hline KI & & & 0,770 & \\
\hline KK & & & $-0,821$ & \\
\hline KM & & & 0,598 & \\
\hline PS & & & & 0,915 \\
\hline PW & & & & 0,545 \\
\hline ROA & 0,962 & & & \\
\hline ROE & 0,915 & & & \\
\hline
\end{tabular}

Sumber: Hasil pengolahan data dengan SmartPLS 3.0

Hasil pengujian outer loading menunjukkan bahwa indikator komite audit tidak memenuhi persyaratan validitas konvergen dalam mengukur struktur pengelolaan, sedangkan indikator kepemilikan keluarga dan kepemilikan manajerial tidak memenuhi syarat untuk mengukur struktur kepemilikan. Kemudian, indikator pengungkapan wajib juga tidak memenuhi syarat untuk mengukur transparansi. Oleh karena itu, dalam analisis selanjutnya, indikator komite audit tidak dipergunakan untuk mengukur struktur pengelolaan, sedangkan indikator kepemilikan keluarga dan kepemilikan manajerial tidak dipergunakan untuk mengukur struktur kepemilikan, kemudian indikator pengungkapan wajib tidak dipergunakan untuk mengukur transparansi. Maka, model outer loadingnya dapat dilihat pada model berikut ini:

Tabel 3. Nilai Loading Factor Pada Indikator Untuk Masing - Masing Variabel Laten

\begin{tabular}{|l|l|l|l|l|}
\hline & $\begin{array}{l}\text { Kinerja } \\
\text { keuangan } \\
\text { Y }\end{array}$ & $\begin{array}{l}\text { Struktur } \\
\text { Pengelolaan } \\
\text { X1 }\end{array}$ & $\begin{array}{l}\text { Struktur } \\
\text { kepemilikan } \\
\text { X2 }\end{array}$ & $\begin{array}{l}\text { Transparansi } \\
\text { Z }\end{array}$ \\
\hline DD & & 0,830 & & \\
\hline DK & & 0,882 & & \\
\hline KI & & & 1,000 & 1,000 \\
\hline PS & & & & \\
\hline ROA & 0,960 & & & \\
\hline ROE & 0,918 & & & \\
\hline
\end{tabular}

Sumber: Hasil pengolahan data dengan SmartPLS 3.0

\subsubsection{Validitas Driscriminant}

Pengukuran validitas diskriminan dilakukan menggunakan metode Fornell-Larcker Criterion. Metode Fornell-Larcker Criterion dapat dilakukan dengan membandingkan square roots atas AVE dengan korelasi partikel laten. Variabel dikatakan memenuhi asumsi validitas discriminant apabila akar kuadrat nilai AVE sepanjang garis diagonal lebih besar dari korelasi antara satu konstruk dengan yang lainnya.

Tabel 4. Fornell Larckel Criterion

\begin{tabular}{|l|c|c|c|c|}
\hline & $\begin{array}{c}\text { Kinerja } \\
\text { keuangan Y }\end{array}$ & $\begin{array}{c}\text { Struktur } \\
\text { pengelolaan } \\
\text { X1 }\end{array}$ & $\begin{array}{c}\text { Struktur } \\
\text { kepemilikan } \\
\text { X2 }\end{array}$ & $\begin{array}{c}\text { Transparansi } \\
\text { Z }\end{array}$ \\
\hline $\begin{array}{l}\text { Kinerja } \\
\text { Keuangan Y }\end{array}$ & 0,939 & & & \\
\hline $\begin{array}{l}\text { Struktur } \\
\text { pengelolaan } \\
\text { X1 }\end{array}$ & 0,326 & 0,856 & $-0,107$ & \\
\hline $\begin{array}{l}\text { Struktur } \\
\text { kepemilikan } \\
\text { X2 }\end{array}$ & $-0,137$ & & 1,000 & \\
\hline $\begin{array}{l}\text { Transparansi } \\
\text { Z }\end{array}$ & 0,012 & 0,227 & $-0,340$ & 1,000 \\
\hline
\end{tabular}

Sumber: Hasil pengolahan data dengan SmartPLS 3.0

Hasil pengukuran di atas menunjukkan adanya nilai akar AVE variabel yang sama lebih tinggi dari pada nilai akar AVE pada variabel yang berbeda. Hal ini menunjukkan bahwa kriteria uji validitas diskriminan telah terpenuhi. Dengan demikian instrumen yang digunakan dalam penelitian ini telah memenuhi semua ketentuan uji validitas.

\subsubsection{Composite Realibility dan Cronchbach Alpha}

Pengujian reliabilitas dilakukan untuk melihat keandalan semua indikator untuk mengukur suatu konstruk. Konstruk dikatakan reliabel jika memiliki nilai composite reliability dan cronbach alpha yang tinggi. Nilai yang disarankan untuk nilai composite reliability jika lebih besar dari 0,7 dan nilai cronbach alpha lebih besar dari 0,6. 
Tabel 5. Nilai Composite Reliability

\begin{tabular}{|l|l|l|}
\hline Varibel Laten & $\begin{array}{l}\text { Cronbach's } \\
\text { Alpha }\end{array}$ & $\begin{array}{l}\text { Composite } \\
\text { Reliability }\end{array}$ \\
\hline Kinerja Keuangan Y & 0,870 & 0,937 \\
\hline Struktur pengelolaan X1 & 0,638 & 0,846 \\
\hline Struktur kepemilikan X2 & 1,000 & 1,000 \\
\hline Transparansi Z & 1,000 & 1,000 \\
\hline
\end{tabular}

Sumber: Hasil pengolahan data dengan SmartPLS 3.0

Berdasarkan tabel di atas dapat dilihat bahwa:

a. Nilai composite reliability untuk variabel kinerja keuangan sebesar 0,937 lebih besar dari 0,7 sedangkan nilai Cronbach alpha - nya sebesar 0,870 lebih besar dari 0,6. Hal ini menunjukkan bahwa hasil pengukuran pada variabel kinerja keuangan reliabel dan data yang dihasilkan bisa diandalkan untuk menjelaskan dengan baik variabel kinerja keuangan.

b. Nilai composite reliability untuk variabel struktur pengelolaan sebesar 0,846 lebih besar dari 0,7 sedangkan nilai Cronbach alpha - nya sebesar 0,638 lebih besar dari 0,6. Hal ini menunjukkan bahwa hasil pengukuran pada variabel struktur pengelolaan reliabel dan data yang dihasilkan bisa diandalkan untuk menjelaskan dengan baik variabel struktur pengelolaan.

c. Nilai composite reliability untuk variabel struktur kepemilikan sebesar 1,000 lebih besar dari 0,7 sedangkan nilai Cronbach alpha - nya sebesar 1,000 lebih besar dari 0,6. Hal ini menunjukkan bahwa hasil pengukuran pada variabel struktur kepemilikan reliabel dan data yang dihasilkan bisa diandalkan untuk menjelaskan dengan baik variabel struktur kepemilikan.

d. Nilai composite reliability untuk variabel transparansi sebesar 1,000 lebih besar dari 0,7 sedangkan nilai Cronbach alpha - nya sebesar 1,000 lebih besar dari 0,6. Hal ini menunjukkan bahwa hasil pengukuran pada variabel transparansi reliabel dan data yang dihasilkan bisa diandalkan untuk menjelaskan dengan baik variabel transparansi.

\subsection{Pengujian Inner Model}

\subsubsection{Koefisien Path}

Hasil analisis untuk melihat besarnya pengaruh langsung struktur pengelolaan dan struktur kepemilikan terhadap transparansi dan kinerja keuangan yaitu sebagai berikut:

Tabel 6. Hasil Pengujian Pengaruh Langsung

\begin{tabular}{|l|l|}
\hline & Koefisien Path \\
\hline Stuktur Pengelolaan X1 -> kinerja keuangan Y & 0,000 \\
\hline Stuktur Pengelolaan X1 -> Transparansi Z & 0,009 \\
\hline Struktur Kepemilikan X2 -> Kinerja keuangan & 0,314 \\
\hline Struktur Kepemilikan X2 -> Transparansi Z & 0,151 \\
\hline Transparansi Z -> Kinerja Keuangan Y & 0,224 \\
\hline
\end{tabular}

Sumber: Hasil pengolahan data dengan SmartPLS 3.0

Berdasarkan tabel di atas dapat dirumuskan hal hal sebagai berikut:
1. Pengaruh struktur pengelolaan terhadap kinerja keuangan dengan koefisien path bernilai positif sebesar 0,000 yang berarti bahwa setiap peningkatan struktur pengelolaan akan meningkatkan kinerja keuangan dengan besarnya pengaruh sebesar $0,000 \times 100 \%=0 \%$

2. Pengaruh struktur pengelolaan terhadap transparansi dengan koefisien path bernilai positif sebesar 0,009 yang berarti bahwa setiap peningkatan struktur pengelolaan akan meningkatkan kinerja keuangan dengan besarnya pengaruh sebesar $0,009 \times 100 \%=$ $0,9 \%$

3. Pengaruh kepemilikan keluarga terhadap kinerja keuangan dengan koefisien path bernilai positif sebesar 0,314 yang berarti bahwa setiap peningkatan struktur kepemilikan akan meningkatkan kinerja keuangan dengan besarnya pengaruh sebesar $0,314 \times 100 \%=31,4 \%$

4. Pengaruh struktur kepemilikan terhadap transparansi dengan koefisien path bernilai positif sebesar 0,151 yang berarti bahwa setiap peningkatan struktur kepemilikan akan meningkatkan transparansi dengan besarnya pengaruh sebesar $0,151 \times 100 \%=15,1 \%$

5. Pengaruh transparansi terhadap kinerja keuangan dengan koefisien path bernilai positif sebesar 0,224 yang berarti bahwa setiap peningkatan transparansi akan meningkatkan kinerja keuangan dengan besarnya pengaruh sebesar $0,224 \times 100 \%=22,4 \%$

Pengujian pengaruh tidak langsung struktur pengelolaan dan struktur kepemilikan terhadap kinerja keuangan yang dimediasi oleh transparansi dapat dilihat pada tabel berikut ini:

Tabel 7. Hasil Pengujian Pengaruh Tidak Langsung

\begin{tabular}{|l|c|}
\hline & Koefisien Path \\
\hline $\begin{array}{l}\text { Struktur pengelolaan -> transparansi } \\
->\text { kinerja keuangan }\end{array}$ & 0,329 \\
\hline $\begin{array}{l}\text { Struktur kepemilikan -> } \\
\text { transparansi -> kinerja keuangan }\end{array}$ & 0,407 \\
\hline
\end{tabular}

Sumber: Hasil pengolahan data dengan SmartPLS 3.0

Berdasarkan tabel diatas dapat dirumuskan bahwa:

1. Pengaruh struktur pengelolaan secara tidak langsung terhadap kinerja keuangan yang dimediasi oleh transparansi dengan nilai koefisien path bernilai positif sebesar 0,329 . Hal ini berarti bahwa besarnya pengaruh tidak langsung struktur pengelolaan terhadap kinerja keuangan yang dimediasi oleh transparansi sebesar $0,329 \times 100 \%=$ $32,9 \%$

2. Pengaruh struktur kepemilikan secara tidak langsung terhadap kinerja keuangan yang dimediasi oleh transparansi dengan nilai koefisien path bernilai positif sebesar 0,407 . Hal ini berarti bahwa besarnya pengaruh tidak langsung struktur kepemilikan terhadap kinerja keuangan yang dimediasi oleh transparansi sebesar 0,407 x 100\% = $40,7 \%$. 


\subsubsection{Pengujian Hipotesis}

Kriteria pengujian hipotesis yang digunakan yaitu dengan membandingkan nilai $p$-value hasil pengujian hipotesis dengan taraf signifikansi 0,05 . Jika $p$-value $\leq$ 0,05 , maka hipotesis statistik diterima dengan demikian variabel eksogen berarti memiliki pengaruh langsung yang signifikan terhadap variabel endogennya.

Tabel 8. Hasil Pengaruh Langsung

\begin{tabular}{|l|l|l|}
\hline & T statistic & P value \\
\hline Struktur pengelolaan -> kinerja keuangan & 4,875 & 0,000 \\
\hline Struktur pengelolaan > transparansi & 2,670 & 0,008 \\
\hline Struktur kepemilikan -> kinerja keuangan & 1,063 & 0,288 \\
\hline Struktur kepemilikan -> transparansi & 1,434 & 0,152 \\
\hline Transparansi -> kinerja keuangan & 1,238 & 0,216 \\
\hline
\end{tabular}

Sumber: Hasil pengolahan data dengan SmartPLS 3.0

Berdasarkan tabel di atas dapat dirumuskan hal hal sebagai berikut:

1. Pengaruh struktur pengelolaan terhadap kinerja keuangan dengan nilai $\mathrm{p}$ - value sebesar 0,000 lebih kecil dari taraf signifikansi 0,05 . Hal ini berarti $\mathrm{H}_{0}$ ditolak dan $\mathrm{H}_{\mathrm{a}}$ diterima. Dengan demikian struktur pengelolaan memiliki pengaruh langsung yang signifikan terhadap kinerja keuangan

2. Pengaruh struktur pengelolaan terhadap transparansi dengan nilai $\mathrm{p}$ - value sebesar 0,008 . Hal ini berarti $\mathrm{H}_{0}$ ditolak dan $\mathrm{H}_{\mathrm{a}}$ diterima. Dengan demikian struktur pengelolaa memiliki pengaruh langsung terhadap transparansi

3. Pengaruh struktur kepemilikan terhadap kinerja keuangan dengan nilai $\mathrm{p}$ - value sebesar 0,288 lebih besar dari taraf signifikansi 0,05 . Hal ini berarti $\mathrm{H}_{0}$ diterima dan $\mathrm{H}_{\mathrm{a}}$ ditolak. Dengan demikian struktur kepemilikan tidak memiliki pengaruh langsung yang signifikan terhadap kinerja keuangan

4. Pengaruh struktur kepemilikan terhadap transparansi dengan nilai $\mathrm{p}$ - value sebesar 0,152 . $\mathrm{Hal}$ ini berarti $\mathrm{H}_{0}$ diterima dan $\mathrm{H}_{\mathrm{a}}$ ditolak. Dengan demikian struktur kepemilikan tidak memiliki pengaruh langsung terhadap transparansi

5. Pengaruh transparansi terhadap kinerja keungan dengan nilai $\mathrm{p}-$ value sebesar 0,216 . Hal ini berarti $\mathrm{H}_{0}$ diterima dan $\mathrm{H}_{\mathrm{a}}$ ditolak. Dengan demikian tranparansi tidak memiliki pengaruh langsung terhadap kinerja keuangan.

Pengujian pengaruh tidak langsung stuktur pengelolaan dan struktur kepemilikan melalui transparansi dapat dilihat pada tabel berikut ini:

Tabel 9. Hasil Pengaruh Tidak Langsung

\begin{tabular}{|l|l|l|}
\hline & T statistic & P value \\
\hline $\begin{array}{l}\text { Struktur pengelolaan } \\
\text { kinerja keuangan }\end{array}$ & & \\
\hline $\begin{array}{l}\text { Struktur kepemilikan transparansi -> } \\
\text { kinerja keuangan }\end{array}$ & 1,032 & 0,303 \\
\hline
\end{tabular}

Sumber: Hasil pengolahan data dengan SmartPLS 3.0

Hasil pengujian hipotesis tidak langsung adalah sebagai berikut:
1. Pengaruh struktur pengelolaan terhadap kinerja keuangan melalui transparansi dengan nilai $\mathrm{p}$ value sebesar 0,303 lebih besar dari taraf signifikan 0,05 . Dengan demikian struktur pengelolaan memiliki pengaruh tidak langsung terhadap kinerja keuangan yang dimediasi oleh transparansi

2. Pengaruh struktur kepemilikan terhadap kinerja keuangan melalui transparansi dengan nilai $\mathrm{p}$ value sebesar 0,412 lebih besar dari taraf signifikan 0,05 . Oleh karena itu, struktur kepemilikan memiliki pengaruh tidak langsung terhadap kinerja keuangan yang dimediasi oleh transparansi.

\subsection{3. $R$ Square}

Nilai $\mathrm{R}$ Square $\left(\mathrm{R}^{2}\right)$ dipergunakan untuk mengukur seberapa besar pengaruh variabel laten eksogen tertentu terhadap variabel laten endogen. Menurut Chin et al. (2003) hasil $\mathrm{R}^{2}=0,67$ menunjukkan kekuatan model kuat; $\mathrm{R}^{2}=0,33$ menunjukkan kekuatan moderat dan $\mathrm{R}^{2}=0,19$ menunjukkan kekuatan lemah atau kurang.

Tabel 10. Hasil Uji R Square

\begin{tabular}{|l|l|l|l|}
\hline & R Square & $\begin{array}{l}\text { R Square } \\
\text { Adjusted }\end{array}$ & Kriteria \\
\hline Kinerja keuangan & 0,141 & 0,081 & Lemah \\
\hline transparansi & 0,152 & 0,541 & lemah \\
\hline
\end{tabular}

Sumber: Hasil pengolahan data dengan SmartPLS 3.0

Berdasarkan tabel di atas dapat dijelaskan bahwa:

1. Nilai $R$ square pada model dengan transparansi sebagai variabel endogen yaitu pengaruh struktur pengelolaan dan struktur kepemilikan terhadap transparansi sebesar 0,152 dan tergolong dalam kategori lemah. Nilai $\mathrm{R}^{2}$ juga menunjukkan bahwa struktur pengelolaan dan struktur kepemilikan mampu menjelaskan transparansi sebesar $0,152 \mathrm{x}$ $100 \%=15,2 \%$, yang mana sisanya sebesar $84,8 \%$ dipengaruhi faktor lain yang tidak termasuk variabel penelitian.

2. Nilai $R$ square pada model dengan kinerja keuangan sebagai variabel endogen yaitu pengaruh struktur pengelolaan, struktur kepemilikan, dan transparansi terhadap kinerja keuangan sebesar 0,141 dan tergolong dalam kategori lemah. Nilai $\mathrm{R}^{2}$ juga menunjukkan bahwa struktur pengelolaan, struktur kepemilikan, dan transparansi secara bersama sama mampu menjelaskan kinerja keuangan sebesar $0,141 \mathrm{x} 100 \%=14,1 \%$, dimana sisanya sebesar $85,9 \%$ dipengaruhi faktor lain yang tidak termasuk variabel penelitian.

\subsubsection{Size Effect $F^{2}$}

Nilai $f^{2}$ akan melihat pengaruh substantif konstruk eksogen terhadap konstruk endogen. Penentuan besarnya pengaruh langsung konstruk eksogen terhadap konstruk endogen diklasifikasikan dalam 3 kategori: 0,02 pengaruh kecil, 0,15 pengaruh medium, dan 0.35 pengaruh besar (Setiawan, 2020). 
Tabel 11. Nilai F - Square Pengaruh Setiap Variabel Laten Eksogen Terhadap Variabel Endogen

\begin{tabular}{|l|l|l|}
\hline & $f^{2}$ & Kriteria \\
\hline Struktur pengelolaan -> kinerja keuangan & 0,140 & Kecil \\
\hline Struktur pengelolaan -> transparansi & 0,119 & Kecil \\
\hline Struktur kepemilikan -> kinerja keuangan & 0,020 & kecil \\
\hline Struktur kepemilikan -> transparansi & 0,043 & Kecil \\
\hline Transparansi -> kinerja keuangan & 0,028 & kecil \\
\hline
\end{tabular}

Sumber: Hasil pengolahan data dengan SmartPLS 3.0

Interpretasi nilai $\mathrm{f}^{2}$ dimana besarnya pengaruh struktur pengelolaan tergolong kecil $\left(\mathrm{f}^{2}=0,140\right)$ dan pengaruh struktur pengelolaan terhadap tranparansi juga tergolong kecil $\left(\mathrm{f}^{2}=0,119\right)$. Pengaruh struktur kepemilikan terhadap kinerja keuangan tergolong kecil $\left(\mathrm{f}^{2}=0,020\right)$ dan pengaruh struktur kepemilikan terhadap transparansi juga tergolong kecil $\left(\mathrm{f}^{2}=0,043\right)$. Sementara itu, pengaruh transparansi terhadap kinerja keuangan tergolong kevcil dengan $\left(\mathrm{f}^{2}=0,028\right)$.

\subsection{Pembahasan}

1. Hasil penelitian menunjukkan bahwa pengaruh langsung yang signifikan dari struktur pengelolaan terhadap kinerja keuangan. Dengan meningkatnya struktur pengelolaan ini merupakan hal yang baik dilakukan perusahaan karna akan meningkatkan kinerja perusahaan diantaranya melaksanakan tugas dan tanggung jawab sesuai dengan tugas dan kewajiban sehingga perusahaan telah melakukan good corporate governance sesuai aturan yang berlaku. Hasil ini tidak sejalan dengan penelitian yang dilakukan oleh Sunarwan (2015) dan Sukandar (2014). Dengan demikian peningkatan kinerja keuangan perusahaan yang terdaftar di bursa efek Indonesia tahun 2019 dipengaruhi oleh adanya peningkatan struktur pengelolaan.

2. Hasil penelitian menunjukkan hasil bahwa pengaruh langsung yang signifikan dari struktur pengelolaan terhadap transparansi. Perusahaan yang terdaftar di Bursa Efek Indonesia memiliki jumlah dewan komisaris, dewan direksi, dan komite audit yang sedikit, hal ini membuat tingkat pengawasan berkurang terhadap kegiatan perusahaan dan serta keahlian dan kompetensi yang dimiliki masih lemah atau kurang maksimal yang menghambat kinerjanya. Dengan demikian peningkatan transparansi perusahaan yang terdaftar di bursa efek Indonesia tahun 2019 dipengaruhi oleh adanya peningkatan transparansi.

3. Hasil ini menunjukkan tidak adanya pengaruh langsung yang signifikan dari struktur kepemilikan terhadap kinerja keuangan pada perusahaan yang terdaftar di Bursa Efek Indonesia tahun 2019. Hal ini disebabkan karena pemilik mayoritas ikut dalam pengendalian perusahaan sehingga cenderung bertindak untuk kepentingan mereka sendiri meskipun dengan mengorbankan kepentingan pemilik minoritas.

4. Hasil penelitian ini menunjukkan tidak adanya pengaruh langsung yang signifikan dari struktur kepemilikan terhadap transparansi pada perusahaan yang terdaftar di bursa efek Indonesia tahun 2019. Hasil ini sejalan dengan penelitian yang dilakukan Serly (2015), Alrawashedh et al. (2021) dan Sari et al. (2010) menunjukkan hasil bahwa struktur kepemilikan tidak berpengaruh terhadap pengungkapan. Hal ini karena semakin tinggi tingkat kepemilikan yang dimiliki maka akan membuat semakin rendah tingkat pengungkapan (Serly, 2015).

5. Hasil penelitian menunjukkan tidak adanya pengaruh langsung yang signifikan dari transparansi terhadap kinerja keuangan pada perusahaan yang terdaftar di bursa efek Indonesia tahun 2019. Hal ini menunjukkan melalui hasil pengujian hipotesis dalam persamaan analisis jalur yang menunjukkan bahwa nilai probabilitas koefisien pengaruh transparansi terhadap kinerja keuangan yaitu sebesar 0,216 lebih besar dari taraf signifikansi 0,05 . Besarnya pengaruh transparansi tergolong lemah dengan nilai $\mathrm{f}^{2} 0,028$, sehingga tidak mampu memberikan kontribusi yang signifikan terhadap peningkatan kinerja keuangan pada perusahaan yang terdaftar di bursa efek Indonesia tahun 2019.

6. Hasil penelitian ini menunjukkan tidak adanya pengaruh secara tidak langsung yang signifikan dari struktur pengelolaan terhadap kinerja keuangan melalui transparansi. Serly (2015) menyatakan hal ini tidak berpengaruh dikarenakan direksi dan dewan komisaris yang berjumlah sedikit sehingga mengurangi tingkat pengawasan terhadap kegiatan perusahaan dan keahlian atau kurang maksimal sehingga menghambat kinerjanya. Transparansi bukanlah menjadi tolak ukur yang pasti untuk menilai kinerja keuangan, walaupun adanya transparansi atau keterbukaan dalam memberikan informasi keuangan tetapi tidak sepenuhnya dapat meningkatkan kinerja keuangan (Esni, 2019). Faktor lain yang dapat mempengaruhi kinerja keuangan ialah efektifitas dan efisien dalam pengelolaan keuangan.

7. Hasil penelitian ini menunjukkan tidak adanya pengaruh secara tidak langsung yang signifikan dari struktur kepemilikan terhadap kinerja keuangan melalui transparansi. Hal ini dapat dilihat melalui hasil pengujian hipotesis dalam persamaan analisis jalur yang menunjukkan bahwa nilai probabilitas pengaruh tidak langsung struktur kepemilikan terhadap kinerja keuangan melalui transparansi sebesar 0,412 lebih besar dari taraf signifikansi 0,05. Hal ini berarti transparansi tidak mampu memediasi hubungan antara struktur kepemilikan dengan kinerja keuangan.

\section{SIMPULAN DAN SARAN}

\subsection{Simpulan}

1. Berdasarkan hasil uji variabel struktur pengelolaan berpengaruh secara langsung terhadap kinerja keuangan perusahaan yang terdaftar di bursa efek Indonesia tahun 2019. Hal ini menjelaskan 
peningkatan struktur pengelolaan memberikan dampak langsung yang mempengaruhi peningkatan kinerja keuangan perusahaan.

2. Berdasarkan hasil uji variabel struktur pengelolaan berpengaruh secara langsung terhadap transparansi perusahaan yang terdaftar di bursa efek Indonesia tahun 2019. Hal ini menjelaskan peningkatan struktur pengelolaan memberikan dampak langsung yang mempengaruhi tingkat transparansi perusahaan.

3. Berdasarkan hasil uji variabel struktur kepemilikan tidak berpengaruh secara langsung terhadap kinerja perusahaan yang terdaftar di bursa efek Indonesia tahun 2019. Hal ini menjelaskan peningkatan struktur kepemilikan tidak memberikan dampak langsung yang mempengaruhi kinerja keuangan perusahaan.

4. Berdasarkan hasil uji variabel struktur kepemilikan tidak berpengaruh secara langsung terhadap transparansi perusahaan yang terdaftar di bursa efek Indonesia tahun 2019. Hal ini menjelaskan peningkatan struktur kepemilikan tidak memberikan dampak langsung yang mempengaruhi tingkat transparansi perusahaan.

5. Transparansi tidak berpengaruh langsung terhadap kinerja keuangan pada perusahaan yang terdaftar di bursa efek Indonesia tahun 2019. Hal ini berarti transparansi laporan keuangan tidak memberikan dampak yang signifikan pada kinerja keuangan perusahaan.

6. Struktur pengelolaan tidak memiliki pengaruh tidak langsung terhadap kinerja keuangan melalui transparansi pada perusahaan yang terdaftar di bursa efek Indonesia tahun 2019. Hal ini berarti peningkatan struktur pengelolaan tidak memberikan dampak yang signifikan terhadap kinerja keuangan, sedangkan dengan peningkatan transparansi tidak mempengaruhi peningkatan kinerja keuangan perusahaan.

7. Struktur kepemilikan tidak memiliki pengaruh tidak langsung terhadap kinerja keuangan melalui transparansi pada perusahaan yang terdaftar di bursa efek Indonesia tahun 2019. Hal ini berarti peningkatan struktur kepemilikan tidak memberikan dampak yang signifikan terhadap kinerja keuangan, sedangkan dengan peningkatan transparansi tidak mempengaruhi peningkatan kinerja keuangan perusahaan.

\subsection{Saran}

1. Perusahaan yang terdaftar di Bursa Efek Indonesia harus meningkatkan kembali good corporate governance perusahaan sehingga dapat meningkatkan kinerja keuangan perusahaan.

2. Bagi peneliti selanjutnya, agar dapat melakukan penelitian dengan variabel lain seperti kepemilikan asing, corporate social responsibility, dan kepemilikan pemerintah.

\section{DAFTAR REFERENSI}

Erniwati. (2020). Pengaruh Karakteristik Kepemilikan Terhadap Kinerja Keuangan Perusahaan Dengan Kualitas Audit Sebagai Variabel Pemoderasi Pada Perbankan Yang Terdaftar Di Bursa Efek Indonesia. Jurnal Point Equilibrium Manajenem \& Akuntansi, 2(2), 1-10.

Hastuti, T. D. (2005). Hubungan Antara Good Corporate Governance Dan Struktur Kepemilikan Dengan Kinerja Keuangan (Studi Kasus pada Perusahaan yang listing di Bursa Efek Jakarta). SNA VIII Solo, September, 15-16.

Arifani, R. (2012). Pengaruh Good Corporate Governance Terhadap Kinerja Keuangan Perusahaan (Studi pada Perusahaan yang Tercatat di Bursa Efek Indonesia). Jurnal Ilmiah Mahasiswa FEB, 1 No 12.

Ramadhani, D., Surya, R. A. S., \& Zarefar, A. (2020). Pengaruh Mekanisme Corporate Governance Terhadap Transparansi. Jurnal Kajian Akuntansi Dan Bisnis Terkini, 1(3), 402-423.

Nuswandari, C. (2009). Pengungkapan Pelaporan Keuangan Dalam Perspektif Signalling Theory. Kajian Akuntansi, 1 No 1.

Utami, S. P. (2019). Perbedaan Kinerja Keuangan Pada Family Business Dan Non-Family Business. EProceeding of Management, 6, 3691.

Wiranata, Y. A., \& Nugrahanti, Y. W. (2013). Pengaruh Struktur Kepemilikan Terhadap Profitabilitas Perusahaan Manufaktur di Indonesia. Jurnal Akuntansi Dan Keuangan, 15(1), 15-26. https://doi.org/10.9744/jak.15.1.1526

Jensen, M. C., \& Meckling, W. H. (1976). Theory of the firm: managerial behavior, agency costs, and ownership structure. Journal of Financial Economics, 3.

Astuti, A. D. (2015). Pengaruh Kepemilikan Keluarga Terhadap Kinerja Perusahaan Dengan Agency Cost Sebagai Variabel Moderating. Jurnal Dinamika Akuntansi, 7.

Lastanti, H. S., \& Salim, N. (2019). Pengaruh Pengungkapan Corporate Social Responsibility, Good Corporate Governance, Dan Kinerja Keuangan Terhadap Nilai Perusahaan. Jurnal Akuntansi Trisakti, 5(1), 27. https://doi.org/10.25105/jat.v5i1.4841

Candradewi, I., \& Sedana, I. (2016). Pengaruh Kepemilikan Manajerial, Kepemilikan Institusional Dan Dewan Komisaris Independen Terhadap Return on Asset. E-Jurnal Manajemen Universitas Udayana, 5(5), 255207.

Wijaya, V. A., \& Christiawan, Y. J. (2014). Pengaruh Kompensasi Bonus, Leverage, Dan Pajak Terhadap Earning Management Pada Perusahaan 
Yang Terdaftar Di Bursa Efek Indonesia Tahun 2009-2013. Tax \& Accounting Review, 4(1), 1-9.

Agusti, R., \& Pramesti, T. (2013). Pengaruh Asimetri Informasi, Ukuran Perusahaan, Kepemilikan Manajerial Terhadap Manajemen Laba. Jurnal Akuntansi, 17(1), 1-10.

Hunardy, N., \& Tarigan, J. (2017). Pengaruh Kepemilikan Pemerintah Terhadap Kinerja Keuangan Melalui Dewan Komisaris Independen Sebagai Variabel Intervening. Business Accounting Review, Volume 5(No. 2), 602-604. http://publication.petra.ac.id/index.php/akuntansibisnis/article/view/6636/6018

Claessens, S. (2006). Corporate governance and development. World Bank Research Observer, 21(1), 91-122. https://doi.org/10.1093/wbro/lkj004

Dahlan, D. (2019). Pengaruh Penerapan Prinsip Good Corporate Governance (GCG) Terhadap Peningkatan Kualitas Pelayanan Di Pt Bank Btpn Tbk Cabang Padang. Alfuad: Jurnal Sosial Keagamaan, 2(2), 266. https://doi.org/10.31958/jsk.v2i2.1442

Rahmawati, I. A. (2017). Pengaruh dewan direksi, dewan komisaris, komite audit dan Corporate social responsibility Terhadap kinerja keuangan perusahaan. Jurnal Akuntansi Dan Ekonomi, 2(2), 54-70.

Sukandar, P. P. (2014). Pengaruh Ukuran Dewan Direksi Dan Dewan Komisaris Serta Ukuran Perusahaan Terhadap Kinerja Keuangan Perusahaan. Universitas Diponegoro.

Effendi, M. A. (2016). The Power Of Good Corporate Governance Teori dan Implementasi (2nd ed.). Salemba Empat.

Fransisca W, M. (2013). Pengaruh Dewan Direksi, Komisaris Independen, Komite Audit, Kepemilikan Manajerial dan Kepemilikan Institusional Terhadap Kinerja Keuangan. Jurnal Ilmu Manajemen (JIM), l(1).

Dewi, P. P., Mendonca, C., Rego, D., \& Bonus, K. (2018). Kompensasi Bonus , Kepemilikan Keluarga Dan Manajemen Laba. Jurnal Ilmiah Akuntansi, 3(1), 71-81.

Tsai, M. T., \& Tung, W. H. (2014). Corporate governance, resources, FDI commitment and firm performance: Empirical analyses of Taiwanese high-tech firms. Chinese Management Studies, 8(3), 313-332. https://doi.org/10.1108/CMS-082012-0118

Shin-Ping, L., \& Tsung-Hsien, C. (2009). The determinants of corporate performance: A viewpoint from insider ownership and institutional ownership. Managerial Auditing Journal, 24(3), 233-247. https://doi.org/10.1108/02686900910941122
Rivandi, M. (2018). Pengaruh intellectual capital disclosure, kinerja keuangan, dan kepemilikan manajerial terhadap nilai perusahaan. Jurnal Pundi, 2(1), 41-54. https://doi.org/10.31575/jp.v2i1.61

Amrin, A. (2018). Karakteristik Perusahaan Dalam Praktik Pengungkapan Wajib Pada Laporan Keuangan Perbankan Syariah Di Indonesia. Jurnal BISNIS \& KEWIRAUSAHAAN, Vol 7 No 4, 346-359. 